\title{
Pelatihan Jurnalistik dalam Membangun Literasi Media pada Anak-Anak di Sanggar Ar-Rosyid Purwokerto
}

Adita Miranti ${ }^{1}$, Ade Tuti Turistiati ${ }^{2}$, Prita Suci Nurcandrani ${ }^{3}$, Audito Anindya Bayu Aji ${ }^{4}$, Raja Satria Wibawa $^{5}$, Anggita Ramadisa ${ }^{6}$

Prodi Ilmu Komunikasi, Fakultas Bisnis dan Ilmu Sosial, Universitas Amikom Purwokerto, Indonesia 1,2,3,4,5,6

adita.miranti@amikompurwokerto.ac.id, ade.tuti@amikompurwokerto.ac.id, prita.suci@amikompurwokerto.ac.id

\section{ARTICLE INFO}

\section{Keywords:}

Training

journalism,

media literacy

children

\section{ABSTRACT}

The number of children who overuse the device makes them less creativ in writing and telling stories. In addition, children sometimes access news tha is not suitable for them, such as scenes of violence, pornography, and porno action. This condition also occurs in children in Ar-Rosyid Purwokertc Community Service Program (PKM) in the form of journalistic training $i$ conducted to build media literacy by developing children's creativity in th field of journalism, both in the form of writing and in the form $c$ broadcasts.This training was held by lecturers and students of th Communication Studies Program at Universitas Amikom Purwokerto in mi September and October 2019 (every Saturdays). There were 20 elementary an. junior high school students participated in this training. They joined the non formal activities in Ar-Rosyid Purwokerto. The facilitators assisted th participants and provided them with knowledge and skills related to th journalistic principles and elements. The participants gained knowledge an skills on how to conduct interviews and observation, and write news accordin. to journalistic rules. In addition, the participants gained experience about th radio broadcasting process and making journalism photos. The trainin started from the orientation, introduction of journalism for children journalistic practices for children, practice, and evaluation. All steps wer carried out at Universitas Amikom Purwokerto.After the training, th participants' interest in writing article and stories are improving. Th participants can write free themes using journalistic elements. In addition: they are confident to do deliver their simple speech in front of audience as wei as in the radio broadcasting.

\section{A. PENDAHULUAN}

Fenomena anak-anak berlebihan menggunakan gawai tidak hanya terjadi di perkotaan tetapi juga di daerah seperti Purwokerto. Banyak anak-anak di Purwokerto menggunakan gawai, seperti untuk berkomunikasi dengan temannya melalui aplikasi media sosial, menonton berbagai konten di kanal Youtube, main games, membaca bermacam informasi online dari berbagai sumber, dan lain-lain.

Anak-anak adalah khalayak atau penonton yang cenderung pasif. Mereka seringkali mudah terpengaruh oleh konten media. Refleksi pengaruh konten media pada anak-anak dapat terlihat dari sikap dan perilaku anak-anak di Sanggar Ar-Rosyid, Purwokerto. Keterampilan komunikasi seperti menulis dan bercerita (lisan) mereka masih kurang baik atau perlu ditingkatkan. Berdasarkan informasi dari pengurus dan guru Sanggar Ar-Rosyid, anak-anak di Sanggar Ar-Rosyid sering mengalami hambatan untuk mengungkapkan ide mereka baik dalam bentuk tulisan maupun lisan (bercerita). Tulisan dan cerita mereka belum bahkan tidak terstruktur, kontennya kadang-kadang kurang sesuai dengan usia mereka, pemilihan kata-katanyanya kurang tepat, dan kalimat yang ditulis atau diceritakan tidak lengkap.

Berdasarkan kondisi di atas, guru di Sanggar Ar-Rosyid merasa perlu diadakannya pengenalan dan pelatihan jurnalistik untuk anak-anak di Sanggar Ar-Rosyid. Pengetahuan tentang dunia jurnalistik sangat penting ditanamkan kepada anak-anak di era milenial. Hal ini dikarenakan banyaknya konten media yang kurang cocok untuk anak-anak seperti adegan kekerasan, pornografi, 
hingga pornoaksi. Fungsi media seharusnya untuk memberikan informasi dan edukasi bagi masyarakat termasuk anak-anak.

Pelatihan jurnalistik ini bertujuan untuk melatih kreativitas anak-anak yang tergabung di dalam sanggar Ar-Rosyid dalam menulis, bercerita dan menginterpretasikan apa yang mereka lihat dan dapatkan di lingkungan sekitar. Interpretasi anak-anak kemudian dikembangkan dan dituangkan ke dalam bentuk tulisan dengan menggunakan kaidah-kaidah jurnalistik.

Pelatihan jurnalistik yang dilakukan oleh para dosen dan mahasiswa Ilmu Komunikasi Universitas Amikom Purwokerto ini merupakan salah satu cara untuk meliterasi anak sejak dini serta mendidik mereka dalam menerima informasi yang ditampilkan di media massa. Sanggar Ar-Rosyid adalah tempat pendidikan non-formal yang memiliki berbagai kegiatan yang menunjang kreativitas anak-anak di Purwokerto. Kegiatan-kegiatan yang diselenggarakan oleh sanggar Ar-Rosyid di antaranya: Kelompok bermain, yaitu program bimbingan untuk anak usia 2 sampai 6 tahun dengan waktu belajar setiap hari Senin sampai Sabtu; Bimbingan belajar terdiri dari bimbingan baca tulis, mata pelajaran umum, bahasa Inggris dan komputer. Sasarannya adalah siswa TK, SD, SMP sampai SMA; Private'N Home yaitu program bimbingan belajar dengan mendatangkan tentor ke tempat siswa dengan jumlah siswa didik antara 1 sampai 2 orang; TBM (Taman Bacaan Masyarakat) yaitu layanan peminjaman pustaka untuk siswa, tentor, orang tua, dan masyarakat umum. Buku-buku yang tersedia terdiri dari buku pelajaran, religi, pendidikan, parenting, ekonomi, cerita anak, serta berbagai majalah; TPQ (Taman Pendidikan Al Qur'an) yaitu pendidikan Al Qur'an untuk usia PAUD/TK. SD, SMP dan ibu-ibu. Materi yang disampaikan yaitu materi pelajaran agama di sekolah, IQRO', bahasa Arab, akhlak, hafalan hadits, hafalan doa sehari-hari dan hafalan suratan pendek; Sanggar Pelangi yaitu layanan bimbingan softskill untuk siswa TK dan SD antara lain Pena Sastra, Fun Adventure, Arsitek Cilik, Publik Speaking \& Sains Eksperimen.

Kegiatan pelatihan jurnalistik yang diadakan di Universitas Amikom Purwokerto kepada anakanak sanggar Ar-Rosyid saat ini termasuk kedalam kegiatan Sanggar Pelangi. Anak-anak pernah melakukan kegiatan yang berkaitan dengan jurnalistik seperti kegiatan reportase. Mereka kemudian membuat laporan hasil reportase melalui video yang mereka unggah di kanal Youtube. Namun, pada saat observasi hasil tulisan mereka belum sesuai dengan kaidah- kaidah jurnalistik. Mereka pun masih asing dengan kata jurnalistik, padahal reportase merupakan salah satu kegiatan dalam jurnalistik.

Reportase adalah kegiatan jurnalistik dalam meliput langsung peristiwa atau kejadian di lapangan. Reporter melaporkan apa yang dilihat di lapangan. Reporter juga memberikan tambahan informasi yang ada relevansinya dengan peristiwa yang sedang berlangsung, misalnya, latar belakang peristiwa, maksud dan tujuan, dalam rangka apa peristiwa diadakan, hal serupa kapan pernah diadakan, dan lain-lain (Yurnaldi, 2004).

Jurnalistik didefinisikan sebagai berikut:

"Kegiatan penyiapan, mencari, mengumpulkan, mengolah, menyajikan penulisan, penyuntingan, dan penyampaian berita kepada khalayak melalui saluran media tertentu. Jurnalistik mencakup kegiatan dari peliputan sampai kepada penyebarannya kepada masyarakat. Jurnalistik dalam pengertian sempit disebut juga dengan publikasi secara cetak" (Budiman, 2005)

Sementara itu, Sumadiria menambahkan definisi jurnalistik sebagai suatu kegiatan yang menyiapkan, mencari, mengumpulkan, mengolah, menyajikan, dan menyebarkan berita. Kegiatan jurnalistik dilakukan secara berkala, secepat mungkin dan seluas mungkin dan ditujukan kepada masyarakat umum (Sumadiria, 2005).

\section{Masalah}

Berdasarkan observasi dan wawancara dosen sebagai fasilitator dengan Ketua sanggar Ar-Rosyid, ditemukan 3 (tiga) masalah yang dihadapi anak-anak peserta pelatihan. Pertama, kuranganya pemahaman anak-anak tentang bagaimana menuangkan ide ke dalam bentuk tulisan dan cerita. Kedua, bagaimana mengakses informasi yang dibutuhkan melalui media online dan memanfaatkannya untuk bahan tulisan. Ketiga, bagaimana caranya agar menyampaikan ide/cerita di depan umum dengan lancar dan percaya diri. 


\section{B. METODOLOGI PELAKSANAAN}

Secara umum metode pelaksanaan program pengabdian kepada masyarakat ini mencakup prosedur atau tahapan kegiatan yang dilaksanakan para fasiliator dalam melaksanakan pelatihan. Metode pelaksanaan kegiatan pelatihan jurnalistik ini dibagi kedalam beberapa tahap sebagai berikut:

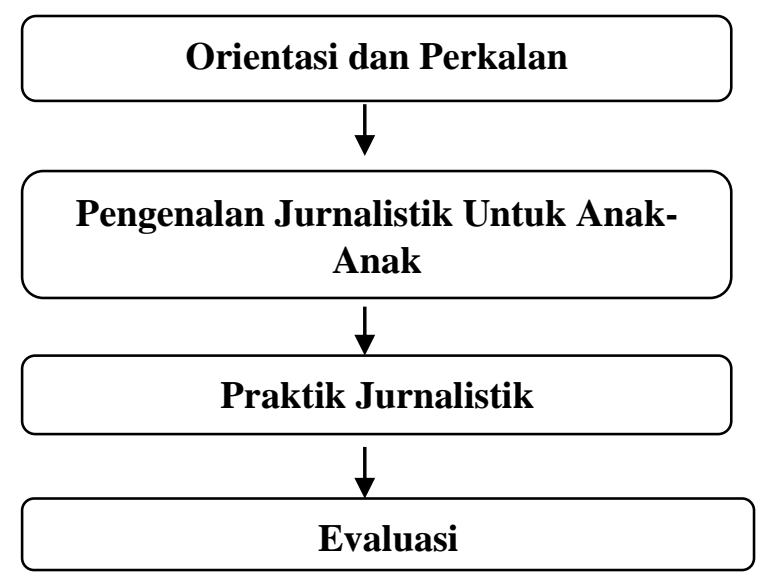

Gambar 1. Tahapan Pelaksanaan Pelatihan Jurnalistik untuk Anak-Anak

\section{Orientasi dan Perkenalan}

Sesi pertama merupakan sesi pembuka berupa perkenalan anak-anak dengan para fasilitator pelatihan. Tujuan dari tahapan ini yaitu untuk menjalin kedekatan emosional para fasilitator dengan peserta dan sebaliknya agar para peserta tumbuh rasa senang dan tertarik untuk belajar. Dengan terbangunnya hubungan yang baik (building rapport) diharapkan proses pelatihan dapat berjalan dengan interaktif dan efektif. Selain berkenalan, anak-anak juga diminta untuk menceritakan keinginan dan harapannya dalam mengikuti pelatihan ini. Sesi ini dilakukan untuk mengetahui pemahaman dan mengukur minat para peserta dalam bidang jurnalistik.

a. Pengenalan Jurnalistik pada Anak

Pada sesi ini fasilitator menjelaskan secara singkat mengenai jurnalistik. Fasilitator memberikan pemahaman mengenai tugas seorang jurnalis yang harus memiliki kepercayaan diri, berani, jujur dan bertanggung jawab. Penjelasan disampaikan dengan memberikan contoh-contoh dalam bahasa yang sederhana sehingga dapat mudah dipahami oleh para peserta. Proses jurnalistik meliput suatu peristiwa menggunakan kaidah atau prinsip $5 \mathrm{~W}+1 \mathrm{H}$. Demikian pula ketika tulisan atau berita disampaikan dalam bentuk presentasi, misalnya jika disampaikan oleh seorang penyiar radio tetap menggunakan kaidah tersebut. Anak-anak dalam sesi ini difasilitasi mengenal bagaimana proses reportase. Setelah itu anak-anak dilatih untuk melakukan wawancara dan menulis sebuah berita yang bersumber pada pengalaman mereka sehari-hari. Di studio broadcasting anak-anak mencoba menjadi seorang penyiar radio dengan konten yang sudah dipersiapkan oleh mereka. Para peserta diberikan pula cara dan tips untuk membuat foto yang memiliki nilai jurnalistik.

\section{b. Praktik Kegiatan Jurnalistik pada Anak}

Pada bagian ini anak-anak praktik membuat sebuah berita dengan menggunakan unsur- unsur berita $5 \mathrm{~W}+1 \mathrm{H}$. Anak-anak menulis berita sesuai dengan tahapannya seperti menentukan berita, membuat judul berita, membuat introduction atau lead berita, mengembangkan berita hingga menutup berita. Sebelumnya, anak-anak telah melakukan kegiatan reportase dengan mencari berita di lapangan, melalui tahapan observasi, wawancara, dan mengolah data yang didapat di lapangan. Pelatihan berikutnya anak-anak diarahkan untuk menjadi penyiar radio serta membuat foto essai jurnalistik. Anak-anak diajarkan mengambil gambar melalui kamera handphone, kemudian diberikan narasi tulisan yang memiliki nilai berita. 
Para peserta berlatih menulis berita yang baik dan benar dengan memenuhi unsur $5 \mathrm{~W}+1 \mathrm{H}$. Charnley mengatakan: Berita adalah laporan tercepat mengenai fakta atau opini yang tertarik atau penting, atau kedua-duanya bagi sejumlah besar penduduk. Pada penulisan berita mengandung unsur- unsur 5W $+1 \mathrm{H}$. (Effendy, 2017)

1) Who (siapa)

Merupakan pertanyaan yang mengandung fakta yang berkaitan dengan setiap orang yang terkait langsung atau tidak langsung dengan kejadian.

2) What (apa)

Merupakan pertanyaan yang akan menjawab apa yang terjadi dan akan mendorong wartawan untuk mengumpulkan fakta yang berkaitan dengan hal-hal yang dilakukan oleh pelaku maupun korban dalam suatu kejadian.

3) Why (mengapa)

Menjawab latar belakang atau penyebab kejadian. Meski jarang, why bisa dipakai untuk membuka sebuah berita atau menjadi lead berita.

4) Where (dimana)

Berkaitan dengan tempat kejadian. Tempat kejadian bisa tertulis detail atau hanya garis besarnya saja. Biasanya, bila berita berasal dari tempat terkenal, maka penulisannya tidak terlalu mendetail.

5) When (bilamana atau kapan)

Menyangkut waktu kejadian. Waktu yang tertera tidak sebatas tanggal, tapi dapat ditulis hari, jam, bahkan menit saat berlangsung sebuah kejadian.

6) How (bagaimana)

Memberikan fakta mengenai proses kejadian yang diberikan. Bisa menceritakan alur kejadian bahkan suasana saat suatu kejadian yang diberitakan tengah berlangsung.

Para peserta juga mendapatkan pengetahuan tentang produk-produk jurnalistik seperti feature. Feature berbeda dengan berita. Berita identik dengan kecepatan dan terikat dengan $5 \mathrm{~W}+1 \mathrm{H}$ namun feature sebaliknya.

"Feature" menurut Williamson adalah artikel yang kreatif, kadang-kadang subjektif yang dirancang terutama untuk menghibur dan memberitahu pembaca tentang suatu peristiwa atau kejadian, situasi atau aspek kehidupan seseorang (Sudarman, 2008).

Romli menambahkan bahwa feature adalah sebuah tulisan jurnalistik. Namun, tidak harus mengikuti rumus klasik $5 \mathrm{~W}+1 \mathrm{H}$ dan bisa dibedakan dengan news, artikel (opini), kolom, dan analisis berita (Romli, 2005). Senada dengan Romli, Sumadiria berpendapat bahwa feature adalah cerita khas kreatif. Feature berpijak pada jurnalistik sastra tentang suatu situasi, keadaan, atau aspek kehidupan. Tujuan feature ini untuk memberi informasi, sekaligus menghibur khalayak media massa (Sumadiria, 2005).

Kegiatan pelatihan jurnalistik ini digabungkan dengan membacakan apa yang peserta tulis melalui siaran di radio dan liputan presentasi dengan menggunakan video. Para peserta dapat mengekspresikan aktivitas-aktivitas jurnalistik dengan lebih fokus.

Pelatihan ini juga mengajarkan bagaimana cara membuat karya jurnalistik berupa foto.

Fotografi Jurnalistik dapat didefinisikan sebagai proses pengambilan gambar yang bertujuan untuk memberitakan suatu peristiwa melalui media massa dengan disertai foto yang memiliki nilai berita dan visual yang kuat. Dengan melihat foto, pembaca bisa menangkap pesan dan berita yang ingin disampaikan mengenai kejadian tersebut.

Menurut Hoy, sebuah foto jurnalistik harus memiliki tiga kriteria untuk dapat dinilai sebagai foto jurnalistik yang baik. Kriteria tersebut antara lain:

a) Kesegeraan: pembaca dapat segera mengerti pesan yang disampaikan, ketika melihat sebuah foto jurnalistik 
b) Memancing emosi: foto jurnalistik harus mampu mengungkap ide dan emosi pembacanya. Sehingga seringkali ditemukan perbedaan persepsi yang unik dari orang-orang yang melihat foto tersebut.

c) Menyajikan sudut pandang: sebuah foto jurnalistik tunggal, akan menyajikan peristiwa hanya dari sebuah sudut pandang. Fakta yang diperlihatkan hanya dari satu sisi peristiwa. (Hoy, 1986)

d) Hoy menambahkan bahwa karakter foto jurnalistik antara lain:

e) Foto jurnalistik merupakan media bagi para jurnalis untuk dapat menyampaikan sebuah informasi kepada publik. Foto jurnalistik akan mengekspresikan pandangan jurnalis, namun pesan yang disampaikan melalui foto tersebut bukanlah ekspresi pribadi;

f) Foto Jurnalistik disebarluaskan melalui media cetak, media siaran, dan internet;

g) Foto jurnalistik merupakan kegiatan pelaporan berita;

h) Foto Jurnalistik merupakan hasil dari perpaduan dua unsur, yaitu gambar dan kata.

i) Acuan dalam foto jurnalistik adalah manusia. Sebab, manusialah pembaca sekaligus objeknya.

j) Foto Jurnalistik berkomunikasi dengan masyarakat luas. Foto jurnalistik harus dibuat sedemikian rupa agar pembaca yang beragam dapat dengan segera menerima pesan yang disampaikan. Pesan yang disampaikan juga harus dibuat;

k) Editor foto juga berperan dalam pembuatan foto jurnalistik. Namun, pengeditan di sini tidak mengubah realitas yang dilihat fotografer ketika foto diambil.

1) Foto Jurnalistik bertujuan untuk menyampaikan informasi kepada masyarakat luas, merunut pada amandemen kebebasan berbicara dan kebebasan pers.

Anak-anak dilatih dan diajarkan untuk membuat foto-foto jurnalistik yang baik dan memiliki visualisasi yang baik dari sisi jurnalistik. Pelatihan jurnalistik ini masih berada pada tingkatan dasar. Targetnya anak-anak paham terhadap sebuah proses pembuatan konten dalam media yang selama ini mereka tonton, baca maupun sekedar melihat. Melalui pelatihan ini, diharapkan anak-anak bertambah pengetahuannya mengenai bagaimana sebuah informasi diproduksi hingga ahirnya menjadi sebuah isi dalam media. Pelatihan ini juga bertujuan merangsang dan mengasah kepekaan anak-anak terhadap keadaan sekitar. Anak-anak diharapkan dapat mendalami secara lebih jauh masalah kemasyarakatan yang mereka dengar dan lihat di luar atau pun di dalam sekolah. Pelatihan ini dapat menjadi sarana bagi anak-anak untuk meningkatkan kreativitas dengan belajar mengelola informasi sederhana dan memiliki pengalaman dan informasi yang lebih banyak ketika berada di lingkungan sosial. Selain itu diharapkan pelatihan ini dapat meningkatkan kepercayaan diri anak-anak.

\section{c. Evaluasi}

Pada bagian ini anak-anak diminta untuk menyerahkan berita yang telah dibuat kemudian menjelaskan berita tersebut di hadapan teman-temannya. Dalam kegiatan ini, anak-anak diminta menceritakan bagaimana pengalaman dan perasaannya selama mengikuti pelatihan. Fasilitator melakukan evaluasi dan tanggapan mengenai paham tidaknya para peserta mengenai materi pelatihan dengan cara tanya jawab lisan dengan para peserta. Fasilitator juga menanyakan apa saja kendala yang dialami anak-anak dalam mengikuti pelatihan. Mahasiswa membantu fasilitator untuk mengarahkan anak-anak pada saat pelatihan berlangsung.

\section{HASIL DAN PEMBAHASAN}

Pelaksanaan pelatihan jurnalistik ini melatih kreativitas peserta (anak-anak) dalam bidang jurnalistik. Pelatihan yang berlangsung selama 4 kali pertemuan ini berjalan dengan lancar dan memberikan hasil yang cukup memuaskan. Pelatihan dilaksanakan setiap hari Sabtu dalam suasana santai tapi serius agar para peserta dapat memahami materi pelatihan dengan baik dan berdampak positif. Pelatihan terlaksana dengan efektif. Hal tersebut dibuktikan dengan tingginya partisipasi dan antusiasme anak-anak dalam mengikuti pelatihan jurnalistik ini. Antusiasme peserta dalam mengikuti pelatihan ditunjukan dengan tugas-tugas yang selalu mereka kumpulkan setiap pertemuan. Fasilitator 
memberikan tugas-tugas kepada anak-anak setiap selesai sesi. Contohnya, anak-anak membuat video tentang lingkungan sekitar, feature tips, dan membuat hasil foto jurnalistik.

Ketika pertama kali datang ke laboraturium broadcasting di Universitas Amikom Purwokerto anak-anak diberikan tontonan yang memiliki pesan moral yang tinggi. Kemudian setelah film berakhir, anak-anak diminta menceritakan kembali menurut sudut pandang masing- masing tentang isi dari film tersebut. Hal ini dilakukan dengan tujuan untuk mengetahui sejauh mana anak-anak memaknai sebuah pesan yang disampaikan dalam tontonan yang diberikan, dan sekaligus mengasah cara berbicara anak-anak di depan umum.

Anak-anak diberikan tugas reportase, yaitu meliput kejadian-kejadian yang sedang terjadi/berlangung disekitar mereka. Mulai dari mewawancarai pedagang, mewawancarai teman teman di sekolah, dan guru di sekolah. Pertanyaan-pertanyaan ringan tersebut kemudian anak-anak ceritakan dalam bentuk tulisan dengan menggunakan kaidah jurnalistik.

Pada pertemuan kedua anak-anak diajarkan cara menulis berita yang baik dan benar sesuai dengan kaidah-kaidah jurnalistik. Anak-anak diberikan tugas untuk menulis berita sesuai dengan unsur $5 \mathrm{~W}+1 \mathrm{H}$, anak-anak yang berjumlah 20 orang di bagi kedalam tiga kelompok, kemudian dibantu dengan tiga orang mahasiswa dari ilmu komunikasi untuk membuat tema berita yang akan mereka tulis berdasarkan $5 \mathrm{~W}+1 \mathrm{H}$. Tujuannya agar anak-anak dapat mengekspresikan pikiran mereka ke dalam tulisan berita. Jika menulis berita identik dengan profesi wartawan namun pelatihan ini mengajak anak-anak berpartisipasi menyumbangkan cara berpikir mereka secara ringan kedalam penulisan berita. Selain itu, $5 \mathrm{~W}+1 \mathrm{H}$ adalah salah satu rumus utama dalam membuat tulisan berita, dengan mengetahui rumus menulis berita tersebut diharapkan kedepannya anak-anak dapat membuat tulisan berita dengan lebih mendalam berdasarkan unsur $5 \mathrm{~W}+1 \mathrm{H}$.

Ketiga, anak-anak diajarkan membuat tulisan feature, salah satunya adalah feature tips. Setelah itu fasilitator menyiapkan materi untuk siaran anak-anak di studio radio. Hal tersebut dilakukan dengan tujuan agar anak-anak mengetahui proses seorang penyiar radio. Mereka biasa nya hanya mendengar melalui radio suara penyiar tanpa mengetahui seperti apa tempat dan proses yang dilakukan seorang penyiar radio sebelum melakukan siaran. Pada tahap ini anak-anak sangat antusias, dan beberapa dari mereka mencoba praktik layaknya penyiar radio sesungguhnya. Fasilitator memberikan arahan serta menjelaskan seperti apa konten yang ada di radio. Apa tugas dari penyiar radio dan cara berbagi dan berbicara secara audio. Dengan tema yang telah disiapkan fasilitator, anakanak mencoba melakukan siaran seperti layaknya penyiar sungguhan. Selain mendapat ilmu dan pengetahuan baru anak-anak juga menjadi lebih percaya diri ketika diminta berbicara kepada orang lain.

Berikutnya, anak-anak diberikan pengarahan tentang apa itu foto jurnalistik. Seperti apa membuat karya foto jurnalistik. Tujuannya adalah anak-anak dapat memahami esensi dari foto secara lebih dalam dan lebih luas. Dan memberikan pengetahuan yang lebih dalam kepada anak- anak bahwa foto memiliki makna visual yang lebih dalam, dalam menciptakan sebuah cerita. Dalam melakukan pelatihan jurnalistik anak-anak sangat bersemangat melakukan kegiatan. Melalui pelatihan ini, anakanak sanggar Ar-Rosyid yang awalnya belum mendapatkan pengetahuan soal menulis dengan baik dan benar, namun setelah pelatihan ini dilakukan perlahan anak-anak jadi mulai mengaplikasikan bagaimana cara menulis berita dengan unsur $5 \mathrm{~W}+1 \mathrm{H}$, selain itu anak-anak dilatih kepekaan menulis feature secara human interest. 


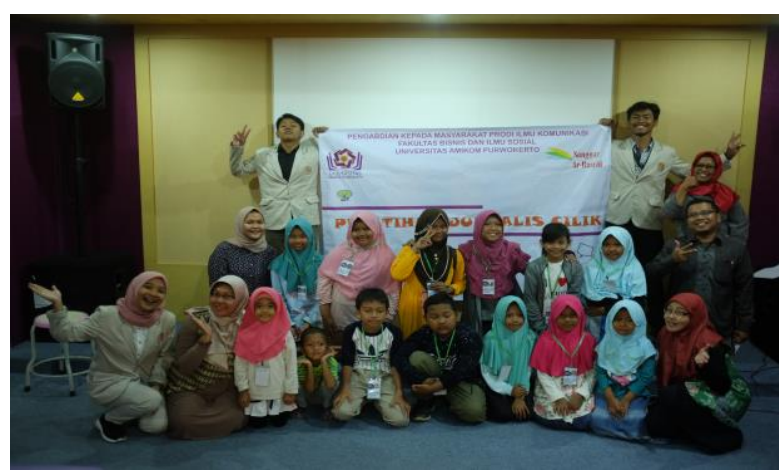

Gambar 2. Fasilitator dan sebagian peserta pelatihan

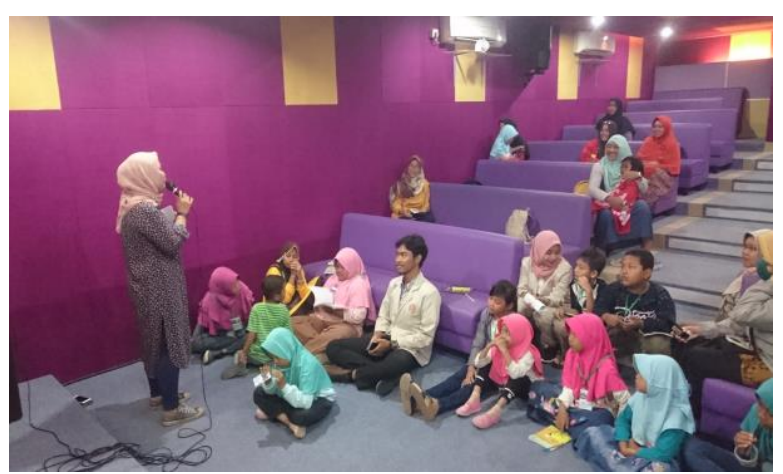

Gambar 3. Fasilitator sedang memberikan penjelasan pada peserta pelatihan dibantu mahasiswa

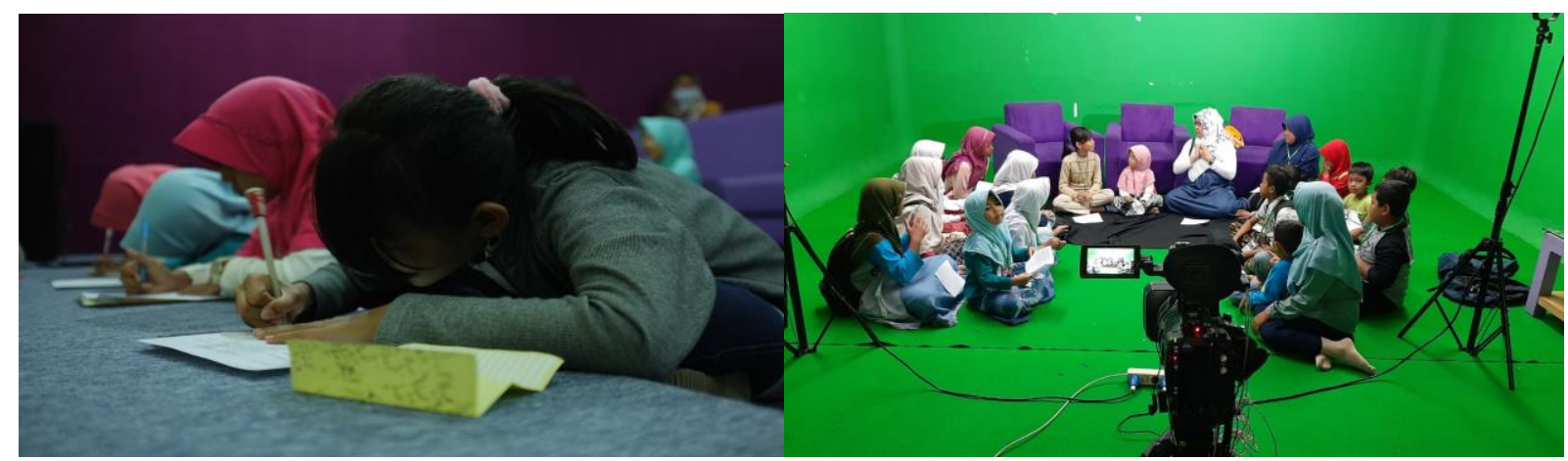

Gambar 4. Peserta sedang menuangkan ide ke dalam bentuk tulisan/berita
Gambar 5. Fasilitator sedang memberikan penjelasan pada peserta pelatihan dibantu mahasiswa

\section{KESIMPULAN DAN SARAN}

Kegiatan PKM dalam bentuk Pelatihan Jurnalis Cilik yang diselenggarakan oleh dosen dan mahasiswa prodi Ilmu Komunikasi Universitas Amikom Purwokerto berjalan efektif. Kreativitas anak-anak sebagai peserta pelatihan dari sanggar Ar-Rosyid meningkat. Para peserta mengikuti pelatihan dengan serius dan antusias. Saat ini, anak-anak sudah mulai terbiasa menulis dengan kaidahkaidah jurnalistik yang baik dan benar. Selain itu, pelatihan jurnalis cilik mampu meningkatkan kepercayaan diri anak-anak dalam berkomunikasi dengan lingkungan secara umum serta menambah pengetahuan mereka pada bidang jurnalistik.

Berdasarkan capaian yang diperoleh, kegiatan PKM ini disarankan dapat dilaksanakan secara berkesinambungan untuk mengevaluasi perkembangan literasi anak-anak. Selain itu, kegiatan serupa dapat dilakukan pada siswa-siswa baru agar mereka mempunyai keterampilan menulis dan bercerita sejak dini

\section{DAFTAR PUSTAKA}

Budiman, K. (2005). Dasar-Dasar Jurnalistik: Makalah yang disampaikan dalam Ishwara, Luwi. 2005.

"Catatan-Catatan Jurnalisme Dasar." Jakarta: Kompas.

Effendy, O. U. (2017). Ilmu Komunikasi Teori Dan Praktik. Bandung: Rosda Karya.

Romli, A. S. (2005). Jurnalistik Praktis Untuk Pemula (Revisi). Bandung: PT. Remaja Rosdakarya.

Sudarman, P. (2008). Menulis di Media Massa. Yogyakarta: Pustaka Pelajar.

Sumadiria. (2005). Jurnalistik Indonesia Menulis Berita dan Feature: Panduan Praktis Jurnalis Profesional. Bandung: Simbiosa Rekatama Media.

Yurnaldi. (2004). Kiat Praktis Jurnalistik. Padang: Angkasa Raya. 